Article

\title{
Examining the Economic Impacts of Climate Change on Net Crop Income in the Ethiopian Nile Basin: A Ricardian Fixed Effect Approach
}

\author{
Melese Mulu Baylie ${ }^{1,2}$ and Csaba Fogarassy ${ }^{3, *(D)}$ \\ 1 Department of Economics, Debre Tabor University, Debra Tabor 272, Ethiopia; meske131621@gmail.com \\ 2 Department of Rural Development Engineering, Hungarian University of Agriculture and Life \\ Sciences (Former Szent Istvan University), 2100 Gödöllő, Hungary \\ 3 Institute of Sustainable Development and Farming, Hungarian University of Agriculture and Life \\ Sciences (Former Szent Istvan University), 2100 Gödöllő, Hungary \\ * Correspondence: fogarassy.csaba@uni-mate.hu
}

check for updates

Citation: Baylie, M.M.; Fogarassy, C. Examining the Economic Impacts of Climate Change on Net Crop Income in the Ethiopian Nile Basin: A Ricardian Fixed Effect Approach. Sustainability 2021, 13, 7243. https:// doi.org/10.3390/su13137243

Academic Editors: Mohammad Valipour, Yu Liu, Baodong Cheng and Qi Cui

Received: 2 June 2021

Accepted: 25 June 2021

Published: 28 June 2021

Publisher's Note: MDPI stays neutral with regard to jurisdictional claims in published maps and institutional affiliations.

Copyright: (c) 2021 by the authors. Licensee MDPI, Basel, Switzerland. This article is an open access article distributed under the terms and conditions of the Creative Commons Attribution (CC BY) license (https:// creativecommons.org/licenses/by/ $4.0 /)$.

\begin{abstract}
Climate change affects crop production by distorting the indestructible productive power of the land. The objective of this study is to examine the economic impacts of climate change on net crop income in Nile Basin Ethiopia using a Ricardian fixed effect approach employing the International Food Policy Research Institute (IFPRI) household survey data for Ethiopia in 2015 and 2016. The survey samples were obtained through a three-stage stratified sampling technique from the five regions (Amhara, Tigray, Benishangul Gumuz, Oromia, and Southern Nation Nationality and People (SNNP) along the Nile basin Ethiopia. There are only $12-14 \%$ female household heads while there are $80-86 \%$ male households in the regions under study. In the regions, more than half of $(64 \%)$ the household heads are illiterate and almost only one-tenth of them (12\%) had received remittance from abroad from their relatives or children. Crop variety adoption rate is minimal, adopted by the $31 \%$ of farmers. Only $30 \%$ of the surveyed farmers mentioned that they planted their crop seeds in row whereas the rest $70 \%$ had not applied this method. The regression results from the fixed effect least square dummy variable model showed that literacy, household size, remittance, asset value, and total land holdings have significant and positive impacts on the net crop income per hectare. The regional dummy variables estimate indicated that all the regions are negatively affected by climate change at varying levels. Strategies to climate change adaptation have significant and positive contributions in leveraging the damaging effects of climate change. The results also showed that increased winter and summer temperature and rainfall increase net crop income per hectare. The estimated coefficient of the interaction term of spring temperature and rainfall is significant and negative. On the other hand, while the mean annual temperature is damaging to crops, annual rainfall is beneficial. It can be deduced that, while increased temperature and rainfall in summer and winter increase the net crop income, the converse is true for winter and spring seasons. The study also proposes a specific, context-dependent, farm-level adaptation analysis of how farmers cope with the different climatic impacts of the Nile Basin and maintain the income levels that they have previously enjoyed.
\end{abstract}

Keywords: climate change adaptation; crop production; Nile Basin Ethiopia; net crop income; Ricardian model; fixed effect model

\section{Introduction}

Over the last three decades, climate change has emerged as one of the unprecedented challenges of the 21st century. Different researchers have come up with different definitions of climate change $[1,2]$. The fluctuation in the level of daily weather conditions, rising sea levels, increasing $\mathrm{CO}_{2}$ concentration and other greenhouse gases have been considered as evidence of global climate change [3]. Global warming and climate change are mainly attributed to and facilitated by market failure resulting from lack of reasonable allocation 
of external costs that challenges the design of appropriate policy orientations [4]. Under the worst-case scenario, it is now estimated that temperature will approximately increase from 1.5 to 5.0 degree Celsius by 2100 [5]. This would potentially alter the patterns of production as well as productivity across regions of the world [6]. Among the economic sectors, agriculture has been substantially affected. A dilemma exists on which path to pursue as the sector is a chief contributor as well a potential sector for mitigating and adapting to the impacts [7]. The relationship between agriculture and climate change can best be explained as a bidirectional one. Practically, globally, agriculture contributes to at least $17 \%$ of the increase in greenhouse gases (GHGs) through releasing carbon dioxide, methane, and nitrous dioxide [8]. The heat-trapping capacity of nitrous oxide and methane is 310 and 21 times stronger than carbon dioxide respectively [9]. Climate change, on the other hand, has posed serious challenges to agricultural production through increasing temperature, varying precipitation and rainfall, drought, extreme events such as flooding and tsunami [10-13]. Platnic and Ronson [14] stated that the agricultural activity, whose main inputs are land, is one of the justifications to human-environment interactions on the planet earth. Climate change is associated with diseases, heavy rainfalls, droughts, pests, and floods $[15,16]$. Climate change affects agriculture directly through carbon dioxide $\left(\mathrm{CO}_{2}\right)$, rainfall, and temperature and indirectly through soil or water which in return emits GHGs [1,2]. This challenge leaves the sector more vulnerable despite its significant role in food security and environmental protection $[17,18]$. To protect the sector against vulnerabilities, increasing its adaptation capacity has become a prerequisite. Adaptation to climate change is defined as the set of strategic approaches and actions [19]; a mechanism tailored by agricultural practitioners [9] to be able to live with climate change without being affected much as a result of the new situation. Adaptation has been designed as one of the curving strategies against climate change [20]. The reason for adaptations is to be able to prepare well with a range of options robust enough to maintain agricultural welfare [21], guarantee higher farm income [22], lessen their vulnerability to climate change impacts [23]. The research team of Scoville-Simonds [24] stated that adaptation has a political dimension and human dimension which resulted in an unequal power in decisionmaking and differences in gender roles respectively [25,26]. Different authors $[27,28]$ stressed the need to promote adaptation-guiding policies that focus on paradigm shift by farmers to a more efficacy and pro-environmental behavior. The adaptation procedure to climate change must be facilitated and guided by capacity building training, agricultural extension services, and climate change education via communication and information technologies as well as radical social and institutional changes [22,23]. But without a clear understanding of the underlying factors, these tools are not effective. For example, they do not reveal the possible positive effects of climate change, which may even affect income changes. The objective of this study is to examine the economic impacts of climate change on net crop income in Nile Basin Ethiopia. Survey 2015 and 2016 examines the economic impacts of climate change on net crop income in Nile Basin Ethiopia using a Ricardian fixed-effects approach. Our research questions are: what climate adaptation strategies can be found in the Ethiopian economic context? What are the heterogeneous effects of climate change on net crop income? What are the impacts that do not fit the proposed models in the literature? The correlation is interesting to examine because the effect of high temperatures can be amplified and mitigated by sufficient precipitation or rainfall, which can have a significant impact on income.

\section{Literature Review}

The agriculture sector in Ethiopia plays a significant role in the economy [29]. To sustain the role, the Ethiopian government over the past two decades has been allocating, on average, $15 \%$ of the national budget to the sector [30]. Despite its significant share from the national budget, the sector continues to struggle from multiple challenges, among them, climate change [30,31]. The sector contributes $35 \%$ to GDP, $68 \%$ to national employment, and more than $90 \%$ to foreign exchange earnings [32,33]. Wheat, teff, barely, sorghum, and 
maize are the major crops produced by smallholder farmers (less than one ha) that account for approximately $95 \%$ of the agricultural land [33]. Ethiopia has varied agro ecological zones that allow the production of different rain-fed crops. The dominant ones are fruits (avocado, apple, banana, orange, lemon, and mango), vegetables (tomato, cabbage, and onion), spices and herbs (mustard, ginger, pepper, and garlic), pulses (vetch, lentils, and horse beans), oil seeds (groundnuts, sunflower, and linseed), stimulants (tea, coffee, and chat), cereals (Oats, Millet, Barely, Sorghum, Wheat, Maize, and Teff) [34]. The country has five main climatic zones based on its diverse topography including Qolla characterized as warm and semiarid ( $<1500 \mathrm{~m}$ above sea level); Woina-dega characterized as cool and subhumid temperate zone (1500-2400 $\mathrm{m}$ above sea level); Cool and humid dega ( $>2400 \mathrm{~m}$ above sea level); Berha characterized as hot arid and Wurch [19]. From an elevation point of view, it can be broadly generalized into three climatic zones as cool, temperate, and hot which are locally known as wurch, woina-dega, and bereha respectively [35]. Although the country has varied agro-ecological zones that allow the production of diversified crops and livestock it would be affected by the change in climate as its average temperature has shown a $0.55^{\circ} \mathrm{C}$ increase between $1971-2010$ and estimated to increase from $0.6^{\circ} \mathrm{C}$ to $0.74{ }^{\circ} \mathrm{C}$ until 2054 [35]. There have been many methodologies that have been used to analyze the impact of climate change on agriculture. According to [17], these methodologies are classified as agriculturefocused and economic focused ones. The difference between these classes of models is emphasis and exposition. Agriculture-focused models aim to estimate crop responses to climate conditions whereas the economic-focused models aim to estimate the economic pressure of variation in crop outputs on the income of farmers. These methodologies are broadly categorized into two: agronomic (agro ecological) approaches and economic (econometric) approaches [36]. Moreover, there is another way of categorization of the methodological approaches to the climate change impact on agriculture. According to this method, the analytical methodologies are classified as partial equilibrium analyses and general equilibrium analyses [37]. Crop simulation models, agro-ecological models, and Ricardian models fall under the partial equilibrium analyses whereas the Computable General Equilibrium model is itself a general equilibrium model. Crop simulation models are based on a controlled field or laboratory experiment settings through which a specific crop's response to climate and other variables is estimated. The models are used to estimate the impact of climate change on agricultural production particularly on crop production by specifying functions that relate the growth rate of crops and climate and crop production management practices and soil varieties [38]. The very interesting aspect of crop simulation models is that they represent the core concepts of agronomic science. They are also capable of being flexible to allow incorporating variables of spatial variation. According to [36], crop simulation models are the simplified presentation of the natural interaction between agricultural-environmental settings in simple controlled experiments. They help to approach the impact of climate change on crop yields from a biophysical perspective. Despite their valuable contribution and application, crop simulation models are criticized for spatial limitation, single crop application, failure to capture farmer behaviors, and other socioeconomic factors as they are only based on agronomic relationships. That does not help to incorporate the effect of adaptation mechanisms. The models assume farmers use the same mode of production systems across time, which in fact is absurd. They underestimate the adaptation roles and thus are suspected of overstating the impact of climate change on agriculture [2]. They are criticized for failing to capture human behavior in the real world agricultural production process [39]. Empirical yield models are the production function models that specify a functional relationship between crop yields and potential determinant variables including climate variables. As [40] stated, the traditional production function approaches tend to overestimate the impact of climate change on yields since it does not incorporate farmer's adaptation to climate change. These types of models are often called "dumb-farmers scenarios" implying a naive behavior of farmers in their production decisions. Because production function methods are based on experimental data, they seem to generate robust estimates of the impacts of climate change on crops 
but they are shrouded with omitted variable bias basically of the profit maximization and adapting strategies of farmers [41]. The earliest economic approach to analyze the impact of climate change on agriculture is that of the Ricardian Method. It was first modeled by Mendelsohn, Nordhaus, and Shaw in 1994 as a deviation to the usual econometric models that control weather in their regression analysis [4]. The premise of this method is land values determined in a perfectly competitive land market. The Ricardian approach is one of the greatest contributions of applied econometrics that help to estimate anticipated economic impacts of climate change [42]. It is another aspect of the hedonic pricing systems or methods used for the economic valuation of environmental resources. It is a measure of the impact of climate change on farm net revenue by regressing on climate variables. In this way, it measures the impact of climate change on welfare [43]. The simplest essence of the model is that land value or net revenue from a farm is a function of agro-climatic variables. One of the strengths of this model is its ability to at least implicitly capture adaptation behaviors of farmers to changing climatic conditions [36]. Advantages of the model are its cost effectiveness relative to other approaches used. The model is also powerful to predict the extent of climate sensitivity of agriculture as a country develops over time [44]. The Ricardian model is not a response function and estimated impacts cannot be deduced to specific crops or livestock [39]. The method, despite its foundational aspect, has been criticized for many drawbacks ranging from misspecification of the model itself to omitting critical variables that could have potential impact on agricultural production. For instance, from the omission of variables point of view, the model has overlooked the impact of price adjustment mechanisms and the time lags, the effect of carbon fertilization effect, prior adaptation experience by farmers, spatial variation of the impact of weather condition variables, and instability in the internal values of estimated. Furthermore, the method is criticized for weak causal identification and not clearly identifying the effect of the interaction of the different types of markets while studying climate change impacts [39]. As its name implies, general equilibrium models try to capture sector-wise interactions and relationships in contrast to the above-mentioned approaches that partially work in the framework of the functioning of specific sectors in an economy. The premise of the general equilibrium models is that they assume that there are channels such as factor substitution, changes in prices, and trade through which each sector interacts with another and climate change impact on the agriculture sector directly and/or indirectly may be disseminated to other sectors too. Thus, general equilibrium models that build on the interactions among sectors are worthwhile [6]. The general equilibrium analysis of the economic impacts of climate change on the agriculture sector of a given country is meant to understand the economy-wise impact of climate change and its consequences on national as well as global climate-oriented policies and adaptation approaches [45]. The application of the cross-sectional Ricardian model has been suspected of being biased because of its limitation to reflect spatial and time variations in the impact of climate change on agriculture. The estimation of the Ricardian model with Panel data has become a vogue and found to be producing more robust and reliable estimates. The first Panel data application of the Ricardian model was developed in 2011 [46] while evaluating the impact of climate change on American agriculture. Estimation of Ricardian models with panel data generates robust, reliable, and stable estimates [46]. Trinh and Frank [17] in their studies on the impact of climate change on Vietnam agriculture using micro-level panel data of ten years produced heterogeneous results which indicate that climate change impact varies across space and time. Luis and Orlando [47] analyzed the impact of climate change on various farming modes such as irrigation, rain fed, and mixed. They reported that irrigated farms are more sensitive to temperature-level fluctuations and the rain-fed ones are sensitive to changes in precipitation. The application of the Ricardian model with panel data on European agriculture by [48] also confirmed that the impact of climate change varies across the different regions of Europe and in the future. A panel data employment of Ricardian model carried out in Hungary [49] assessed that the responsiveness of agricultural production varies between short-run and long-run time horizons and the different agro-ecological 
zones of the country. Estimating the impact of climate change on agriculture simply by following conventional aggregation methods results in biased outcomes. This aggregation bias can be captured by panel data [50]. It is against this background where this study is established to examine the impacts of climate change on net crop income and empirically estimate the leveraging role of adaptation strategies on climate change in the Ethiopian Nile Basin region. The study employed a Ricardian fixed effect approach to determine the effect of climate change on farm net revenue. The Ricardian approach of estimating the impact of climate change on agriculture (crop/livestock) has been widely used in more than forty six countries and five continents [43]. Lack of broader research on economics of climate change in agriculture has resulted in application of different methodologies which to a large extent are contradicting one another [6]. To the best of our knowledge, the Ricardian studies conducted on the economic impact of climate change on Ethiopian Agriculture employed cross-section data based on household surveys [34,45]. None of the studies has also examined the interaction effect of climate variables (temperature and precipitation or rainfall) on farm level net revenue despite its significant impact [51]. The interaction is valuable because the impact of high temperature can be leveraged and lessened by the availability of enough precipitation or rainfall. The rationality behind the choice of the Ricardian approach is that as compared to Agro-Ecological Zone models, it produces modest and negotiating results [6]. Although there is much agreement that increased future temperature would negatively affect agricultural production, various research has shown the presence of heterogeneous impact of climate change [6,48]. This study also tried to examine the contributions of climate change adaptation approaches such as irrigation, use of new and improved crop varieties. Although the Ricardian analysis has been criticized due to heavy overreliance on weather variations instead of climate change, this study employed a 32 years of climate change data ranging from 1983 to 2015 to examine the economic impacts of climate change on net crop income in the Nile basin Ethiopia using panel data-fixed effect model.

\section{Materials and Methods}

Ethiopia is one of the Sub-Saharan countries located in East Africa forming the main body of the Horn of Africa stretching along 3 and 15 North latitude and 33 and 48 East longitude. It is bordered by Kenya in the South, Djibouti and Somalia in the East and South East, Eritrea in the North East, and both Sudan and South Sudan in the West. The total area of the country is more than 1 million $\mathrm{km} 2$ [35]. Ethiopia has a total population of more than 112 million [52]. Only $20 \%$ of its population lives in cities and towns [33]. The country has ten (10) regional and two federal city administration units. These units have different levels of socio-economic and natural resource endowments and processes. However, they have all relatively the same consumption pattern and tax rates [53]. The target area of the study was the Nile river basin part of Ethiopia that includes the five regions (Tigray, Amhara, Oromia, Benishangul Gumuz, and Southern Nation Nationality and People (SNNP)). The data were taken from the dataset of the household survey made by the International Food Policy Research Institute (IFPRI) specifically collected by [54] at a district level from these five regions. The survey was made through a multi-stage stratified sampling technique. First, 20 districts (regions in the context of Ethiopian administrative system) were selected purposely based on already placed criteria such as level of rainfall patterns, four traditional agro-ecological zones, and vulnerability of food production systems (proxied by frequency of food aid received in the last ten years). The distribution of the districts across the regions is: Tigray region (Hawezein, Atsbi Wonberta and Endamehoni), Amhara region (Debark, Chilga, Wogera, Libo kemkem, Bichena, Quarit, Metekel), Oromia region (Gimbi, Haru, Limu, Nunu Kumba, Bereh Aleltu, Hadabu Abote and Keresa), Benishangula Gumuz (Wonbera, Bambasi, and Sirba Abay), and SNNP (Gesha Daka). Second, 20 peasant associations were selected (one from each district) purposively. Third, 50 households were randomly selected from each peasant association for a total sample of 1000 households and these samples were studied for two years which produced unbalanced panel data. 
However, the total samples used in this study are 1695 as missed data for some farmers were removed. Several studies have employed cross sectional data for formulating their Ricardian Model in analyzing the impacts of climate change in agriculture. As presented above, the downfalls associated with cross-sectional data necessitated this study to employ panel data for the study of the impact of climate change on agriculture $[42,46,49,55,56]$. The nature of data employed in this study was a short unbalanced two-years panel data (because observations for 2015 are 857 whereas 838 for 2016), which made this study one of the few Ricardian models that used panel data. The application of panel data helps avoid aggregation bias and produces robust estimates [17]. It also provides more efficiency, higher degrees of freedom, and saves us from camouflaging the existing heterogeneity among the individual households within the regions [57]. Because panel data study the dynamics of change of phenomena [57], it is more suitable to capture the effect of farmer adaptations to climate change and technological change on agriculture. Data on farm characteristics, farm households, crops grown, prices of inputs and outputs, and costs of production came from IFPRI owned by [54] across five regions in Ethiopia (Tigray, Amhara, Oromia, Benishangul Gumuz and SNNP) statically known as Nile Basin Region of Ethiopia. The dataset is identified as "Ethiopia Nile Basin Climate Change Adaptation Dataset" under the category of "Household and Community Levels Survey." Furthermore, data on temperature, rainfall, elevation, and soil type for the farm households were obtained from MarkSim ${ }^{\circledR}$ DSSAT Weather File Generator, which is the MarkSim web version for International Panel for Climate Change fifth Assessment Report (IPCC AR5) data available online at http:/ / gismap.ciat.cgiar.org/ (accessed on 20 May 2021). Net crop income $(\pi)$ (the dependent variable) obtained as $\pi=\mathrm{TR}-\mathrm{TC}$ is weighted by land size in hectare to account for farm productivity per hectare and remedies the issue of heteroscedasticity. Data on climate variables of temperature and rainfall are of seasonal normal (mean) calculated as average of three months in each season that pertains to the Ethiopian year seasonal classification (winter $=$ December, January and February, Spring = March, April, and May, Summer = June, July, and August, and Autumn = September, October, and November). The rationality is to be able to capture the impact of seasonal variation on crop production. Because the rise or fall in temperature or precipitation within the seasons do not have the same effect on the different cereals [17].

\subsection{Model Specification: The State-of-the-Art of the Ricardian Model}

David Ricardo had not actually formulated the current Ricardian model of the study of the impact of climate change. The model is named after him because the concept of the model was derived from his rent theory. It was what Ricardo called "land rent" that we call "land value" or "net profit from farmland." David Ricardo pointed out that the source of land rent is variation in the quality and productivity of land [58]. To put it differently, if it had not been due to the differences in the quality of land and its limitedness, land rent would have never be paid. Thus, soil quality affects land value or land rent. It was this concept of the rent theory of David Ricardo that [40] extended and developed as a model of the study of the impact of climate change on agriculture. The assumption behind the work of these researchers seemed to be that, in addition to soil fertility, climate variables affect land rent (in the word of Ricardo) or land value or net farm revenue per hectare. Furthermore, climate variables shift agricultural production function [17].

The basic model of the Ricardian model was built on the simple profit function known as the difference between total revenue and total cost. The basic model once introduced by Mendelsohn et al. (1994) is now widely used to quantify the impact of climate change on agriculture with contextual modifications. The main assumption of the model is that farmers are rational enough to maximize their profit (net farm revenue). Researchers have the freedom to modify the model based on their research objectives. For instance, ref. [59] formulated the Ricardian model as follows;

$$
M a x \pi=T R-T C=P_{i} Q_{i}(Z c Z n c)-C_{i}(Z n, Z n c)-P l L_{i}(Z n, Z n c)
$$


where, $P_{i}, Q_{i}, C_{i}$ are the prices, outputs, and costs of production respectively. $P l, Z n$, and $Z n c$ are the rental price of land $L_{i}$, vector of controlled land attributes, and vector of non-controlled variables (1). Furthermore, the model assumes that farmland value means the present value of net land revenue [5] and it is formulated as follows:

$$
L V=\left\{\Sigma P_{i} Q_{i}(C, X, Z, I)-P I\right\} e^{-\varphi t} d t
$$

where, $L V=$ land value per hectare, $P i=$ vector of price of output $i, Q i=$ output $i, C=$ vector of climate variables, $X=$ vector of time varying variables (income and population density), $Z=$ vector of time invariant variables (soils and geographic variables), $I=$ vector of economic inputs other than land, $P=$ is price of inputs, $\Phi=$ discount rate, and $t=$ time (2). The farmers, therefore, would strive to maximize their profit or net revenue by choosing the employment of its economic variables given exogenous variables of climate variables.

But because the functional relationship between net revenue of farm land and climate variables has once been established as nonlinear second degree polynomial [3] the nature of the Ricardian model for this study can be approximated as:

$$
L V=\pi=\beta_{0}+\beta_{1} T_{i}+\beta_{2} T_{i}^{2}+\beta_{3} P_{i}+\beta_{4} P_{i}^{2}+\epsilon_{i}
$$

$\pi=$ net crop income, $T_{i} T_{i}=$ temperature in degree Celsius, $T_{i}{ }^{2}=$ temperature squared in degree Celsius, $P_{i}=$ precipitation level, $P_{i}{ }^{2}=$ precipitation squared, and $\epsilon_{i}=$ error term that captures unobserved variables in the model (3).

\subsection{The Empirical Model: Ricardian Fixed Effects Model}

The panel data approach helps to manage omitted variables biased by controlling the effect of time-invariant unobservable variables non-parametrically [39]. The fixed effects model is applied when the interest of the study is to examine the impact of time-varying variables on a dependent variable. It answers the nature of causal relationships between left hand and right hand variables within the panel entities themselves [60]. The fixed effects model takes the following form [60]:

$$
\pi i t=\beta_{i} X_{i t}+\alpha i+\varepsilon i t
$$

where, $\pi i t=$ the dependent variable (net crop income per hectare); $i$ is the regions and $\mathrm{t}$ is the years (2015 and 2016); $X_{i t}$ is the time varying-independent variables; $\beta_{\mathrm{i}}$ are the coefficients of the variables, and sit is the error term (4).

The fixed effects model can also be run by specifying entity-fixed effects on the dependent variable by introducing dummy variables for the entities in which the panel is formed. In this study, entities are the five regions in the Nile basin Ethiopia. Therefore, the regions fixed effects model can be expressed as:

$$
\pi i t=\alpha o+\beta_{1} X_{1}, \text { it }+\cdots+\beta_{n} X_{n}, i t+\delta_{1} R_{1}+\delta_{2} R_{2}+\cdots+\delta_{n} R_{n}+\mu i t
$$

where, $\pi i t$ is the dependent variable (net crop income per hectare); $\beta n$ are the coefficients of independent variables; $X_{n}$ are the independent variables (socio-economic and climate variables). $R_{1} \ldots R_{n}$ are the regional dummies ( $R_{1}=1$ is Tigray, $0=$ otherwise; $R_{2}=1$ is Benishangul Gumuz, $0=$ otherwise; and the reference dummy is Amhara region) $\delta_{1} \ldots$ $\delta_{n}$ are the coefficients of the dummy variables; and $\mu$ it is the error term. Furthermore, the fixed effects model also allows incorporating time effects on the dependent variable through introducing time dummies for the time variable. This permits the fixed effects model to show the fixed effect of time and regions on the dependent variable. In this study the time dummy incorporated is only one since there are two periods in the study (2015 and 2016). Thus, the model can be framed as follows (6):

$$
\pi i t=\alpha o+\beta_{1} X_{1}, \text { it }+\cdots+\beta_{n} X_{n}, i t+\delta_{1} R_{1}+\delta_{2} R_{2}+\cdots+\delta_{n} R_{n}+\theta Y_{1}+\mu i t
$$


where, $\pi$ it is the dependent variable (net crop income per hectare); $\beta n$ are the coefficients of independent variables; $X_{n}$ are the independent variables (socio-economic and climate variables). $R_{1} \ldots R_{n}$ are the regional dummies $\left(R_{1}=1\right.$ is Tigray, $0=$ otherwise; $R_{2}=1$ is Benishangul Gumuz, 0 = otherwise; and the reference dummy is Amhara region) $\delta_{1} \ldots \delta_{\mathrm{n}}$ are the coefficients of the dummy variables; $\theta$ is the coefficient of the time dummy $\left(Y_{1}=1\right.$ is 2015 and 2016 is a reference year), and $\mu$ it is the error term. Panel data fixed effects model is run into Hsiao two steps regression as suggested by [61]. The first step involves regressing net crop income on time varying variables and region fixed effects and the second step involves regressing net crop income on time invariant variables $[46,61,62]$. However, this study has not applied the second step as it results in a higher standard error estimate because of the long run correlation of error terms [46]. More interestingly, the Hsiao first step is simply what is known as the least square dummy variable model (LSDV) [60].

\section{Results}

The main objective of the study was to examine the economic impact of climate change on net crop income $(\pi)$ in the Nile basin Ethiopia. To meet the specific objectives of the study, descriptive analysis and a fixed effects econometric model were used. The descriptive analysis involves presentation of data in actual value number, frequency, percent, and mean, standard deviation minimum and maximum values of the variables used in the study. Furthermore, dummy variables are presented in frequency and percentage methods of data presentations. On the other hand, continuous variables are described in measures of central tendencies of mean, standard deviation, minimum, and maximum.

\subsection{Dummy Variables of the Analyis}

Table 1 below shows frequency and the associated percentage share of attributes in each dummy variable. The dummy variables used in the study are gender $(1=$ male, $0=$ female); literacy $(1=$ literate, $0=$ illiterate $)$; and remittance $(1=$ if received remittance, $0=$ if had not received). Moreover, crop variety ( $1=$ used crop variety, $0=$ had not used); row plantation $(1=$ if the farmer had applied row plantation of crops, $0=$ had not applied); irrigation ( $1=$ if the farmer used irrigation, $0=$ had not used) were included in the study.

Table 1. Dummy farmer and farm characteristics.

\begin{tabular}{cccc}
\hline Variables & Attribute & Frequency & Percent \\
\hline Gender & Male (1) & 1465 & $86 \%$ \\
& Female (0) & 230 & $14 \%$ \\
Literacy & Literate (1) & 612 & $36 \%$ \\
Remittance & Illiterate (0) & 1083 & $64 \%$ \\
& Received (1) & 198 & $12 \%$ \\
Crop variety & Had not received (0) & 1497 & $88 \%$ \\
& Used (1) & 526 & $31 \%$ \\
Irrigation & Had not used (0) & 1169 & $69 \%$ \\
& Used (1) & 7619 & $4.5 \%$ \\
\hline
\end{tabular}

Source: Own calculation based on IFPRI (2015 and 2016) survey data in Ethiopian Nile basin.

As one can see from Table 1 above, there are only 14\% (230) female household heads while there are $86 \%$ (1465) male households in the regions under study. In this region, more than half of $(64 \%)$ the household heads are illiterate and almost only one-tenth of them $(12 \%)$ had received remittance from abroad from their relatives or children in the form of capital inflow into the region. Crop variety adoption rate is minimal since only $31 \%$ of the farm households had reported that they had adopted new crop varieties. Only $30 \%$ of the surveyed farmers reported that they planted their crop seeds in row whereas the rest $70 \%$ had not applied this method. Furthermore, irrigation was found to be an alternative adaptation to drought and rainfall shortage problems in climate change prone regions in the country. In the Nile basin region, which is the target area of the study, almost no 
farmer $(4.5 \%)$ had been a beneficiary of the irrigation scheme as an adaptation method to drought and rainfall shortage. This is evident as less than $1 \%$ agricultural land in Ethiopia is irrigated in Ethiopia [36].

\subsection{Descriptive Analysis of for the Discrete and Continuous Socio-Economic Variables}

Table 2 below, presents the descriptive statistics (mean, standard deviation, minimum, and maximum) for the discrete and continuous socio-economic variables used in the study. Thus, the mean value of net crop income per hectare of land is 47,093.5 Ethiopian Birr. The mean age of household heads is approximately 52 years. The maximum age is 99 years. The region has an average family size of eight (8) members in a given household. The average total land holding in hectares is approximately two (2) hectares while the maximum is 19 hectares. The mean total area (size) of a plot is 0.44 hectare that implies high land fragmentation.

Table 2. Descriptive statistics of the continuous socio-economic variables.

\begin{tabular}{|c|c|c|c|c|c|}
\hline Variables & Observations & Mean & Std.Dev & Min & $\operatorname{Max}$ \\
\hline Net crop income/h & 1695 & $47,093.49$ & $40,214.4$ & 0.54 & $434,847.8$ \\
\hline Age & 1695 & 51.84012 & 13.00435 & 20 & 99 \\
\hline hhsize & 1695 & 8 & 2.4 & 1 & 19 \\
\hline Assetvalue & 1695 & $28,456.24$ & $69,791.13$ & 0 & $2,059,905$ \\
\hline Land in hectare & 1695 & 1.9 & 1.36 & 0 & 13 \\
\hline Average plot size & 1695 & 0.44 & 3.98 & 0.01 & 163 \\
\hline
\end{tabular}

Source: Own calculation based on IFPRI (2015 and 2016) survey data in Ethiopian Nile basin.

\subsection{Descriptive Analysis of the Seasonal Climate Variables}

Temperature and rainfall climate variables were calculated based on the traditional four seasons that correspond to the four main agro-ecological zones dominantly experienced in the country. The following table presents the mean, standard deviation, minimum and maximum values of the seasonal as well as the annual temperature and rainfall.

As one can understand from the above Table 3, the maximum average temperature record is $26.38^{\circ} \mathrm{C}$ that is in spring season whereas the minimum average temperature record is $13.85{ }^{\circ} \mathrm{C}$ in the winter season. The standard deviation values for all temperature seasons are approximately the same that indicates that the seasonal temperature is normally distributed. In addition, mean seasonal and annual temperature values are close to each other. When it comes to rainfall, the minimum average rainfall recorded is $1.44 \mathrm{~mm}$ whereas the maximum average rainfall is $311.5 \mathrm{~mm}$. As the standard deviation column indicates, there is a large variation in the rainfall distribution across seasons each year. The minimum rainfall season is winter whereas the maximum rainfall season is summer. This is because summer in Ethiopia is the rainy season and winter is a dry season almost in all parts of the country.

\subsection{Model Regression Results}

The main objective of the study was to examine the economic impacts of climate change on net crop income in the Nile basin Ethiopia using a Ricardian fixed effects panel data model. The study also aimed at examining the effects of methods of climate change adaptations on net crop income. 
Table 3. Descriptive statistics for seasonal average temperature and rainfall in the Nile basin region from 1983-2015.

\begin{tabular}{cccccc}
\hline Variables & Observations & Mean & Std.Dev & Min & Max \\
\hline Winter_T & 1695 & 18.7 & 2.5 & 13.85 & 24.7 \\
Spring_T & 1695 & 20.25 & 2.36 & 16.39 & 26.38 \\
Summer_T & 1695 & 18.34 & 1.85 & 14.83 & 23.29 \\
Autumn_T & 1695 & 18.35 & 2.09 & 14.66 & 23.63 \\
Annual_T & 1695 & 18.9 & 2.13 & 15.40 & 24.62 \\
Winter_R & 1695 & 10.50 & 11.8 & 1.44 & 50.14 \\
Spring_R & 1695 & 75.28 & 39.11 & 33.42 & 171.8 \\
Summer_R & 1695 & 244.0 & 56.48 & 101.03 & 311.5 \\
Autumn_R & 1695 & 99.00 & 46.99 & 22.68 & 179.42 \\
Annual_R & 1695 & 97.00 & 32.50 & 32.96 & 150.20 \\
\hline
\end{tabular}

Source: Own calculation based on IFPRI (2015 and 2016) survey data in Ethiopian Nile basin.

Table 4 above presents the regression results of the LSDV model of net crop income on time varying variables and regional fixed effects. It presents the impact of time-varying variables (farmer characteristics, farm characteristics, and climate variables) on net crop income by controlling for the impact of time-invariant variables that are attributed to each panel region. The fixed effects model, therefore, helps to remove the within region correlation of error terms and the explanatory variables that belong to a given region. The fixed effect also assumes that each panel region (entity) has unique time-invariant characteristics that exclusively pertains to that entity only and therefore, there is no correlation between the error terms of the different regions $[46,60]$. Thus, the regression result shows that age has a highly statistically significant negative impact on crop net income in the Nile basin Ethiopia. Household size has also a highly statistically significant positive influence on net crop income. When it comes to the impact of seasonal mean temperature and rainfall, we found heterogeneous results as the coefficients of seasonal temperatures and rainfall indicate. To start with, mean summer temperature and autumn temperature have a highly statistically significant (1\%) positive and negative impact on net crop income respectively. All mean seasonal rainfall variables have a positive impact on net crop income except autumn season although with varying statistical significance level. Mean autumn rainfall has a significant and negative impact (5\%) whereas spring rainfall has a positive but insignificant effect. The year and region dummies incorporated in the LSDV model also shows heterogeneous impacts on net crop income. The year dummy $\left(\mathrm{Yr}_{-} 2\right)$ which stands for 2016 shows that net crop income in 2016 is less than the net crop income obtained in 2015 by 4281 Ethiopian birr. When it comes to the regional dummy coefficients, we can see that all the regions except the Amhara region (the reference regional dummy with positive but insignificant coefficient) have statistically significant negative coefficients. SNNP is the most highly affected region receiving 44,025 Ethiopian birr less than Amhara region. The second most affected region is the Oromia region with 36,338 birr less relative to the reference region. Benishangul Gumuz is the least affected region as it is 144 birr less than that of Amhara region. The regional dummy coefficients indicate that living in each region has an impact on the net crop income obtained. However, because the coefficient of the reference dummy region (Amhara region) is statistically insignificant, there is no evidence that there is real difference in the net crop income of farmers in the different regions. The results also proved that irrigation and improved crop variety have significant and positive effects on net crop income by leveraging the negative impacts of climate change. Net crop income was also regressed on squared and interaction terms of the seasonal temperature and rainfall as Table 5 shows below under column (A) and column (B) respectively. 
Table 4. Regression result of Hsiao first-step method (LSDV).

\begin{tabular}{crcr}
\hline Netcropincomec $(\pi)$ & Coefficients & Netcropincomec $(\pi)$ & Coefficients \\
\hline Age & $-202.05^{* * *}$ & Spring_R & 3.23 \\
\hline Hhsize & $1767.52^{* * *}$ & Summer_R & $313.29^{* * *}$ \\
\hline Assetvalue & $0.03^{* *}$ & Autumn_R & $-213.126^{* *}$ \\
\hline Land in hectare & $2705.222^{* * *}$ & Yr_2 & $-4281.3^{* *}$ \\
\hline Irrigation & $10,735.12^{* *}$ & Benishangul Gumuz & $-36,338.36^{* * *}$ \\
\hline Improved-crop-variety & $4264.8^{* *}$ & Oromia & $-44,025^{* * *}$ \\
\hline Spring_T & 4455 & SNNP & $-22,616.7^{* * *}$ \\
\hline Summer_T & $17,887.9^{* * *}$ & Tigray & $-22,616.7^{* * *}$ \\
\hline Autumn_T & $-21,688.24^{* * *}$ & Constant & 32,055 \\
\hline Winter_R & $1309.7^{* *}$ & Observation $=1683$ & $\mathrm{R}^{2}=0.17$ \\
\hline Legend: ${ }^{* * *} p<1 \%,{ }^{* *} p<5 \%,{ }^{*} p<10 \%$ & & \\
\hline Source: Own calculation based on IFPRI $(2015$ and 2016$)$ survey data in Ethiopian Nile basin. &
\end{tabular}

Table 5. The impacts squared and interaction terms of mean seasonal temperature and rainfall on net crop income.

\begin{tabular}{|c|c|c|c|}
\hline Netcropincomeh $(\pi)$ & Coefficients (A) & Netcropincomeh $(\pi)$ & Coefficients (B) \\
\hline Winter_T_sq & $1110.65^{* * *}$ & Winter_T*Winter_R & $4.97^{* * *}$ \\
\hline Spring_T_sq & $-914.8^{* * *}$ & Spring_T $*$ Spring_R & $-3.62^{* * *}$ \\
\hline Summer_T_sq & $372.655^{* * *}$ & Summer_T * Summer_R & $3.93^{* * *}$ \\
\hline Autumn_T_sq & $-478.6^{* *}$ & Autumn_T * Autumn_R & -0.61 \\
\hline Winter_R_sq & $22.12 * *$ & Annual_T & -1.59 \\
\hline Spring_R_sq & $-3.6^{* * *}$ & Annual_R & $6.28^{* * *}$ \\
\hline Summer_R_sq & $0.7^{* * *}$ & _constant & $30,497^{* * *}$ \\
\hline Autumn_R_sq & $-1.42^{* * *}$ & & \\
\hline Yr_1 & $4285.8^{* *}$ & & \\
\hline _constant & $59,384.5^{* * *}$ & $\mathrm{R}^{2}$ : within $=0.0256$ & \\
\hline $\mathrm{R}^{2}$ between $=0.55$ & $n=1695$ & $n=1695$ & \\
\hline Legend & ${ }^{* * *} p<1 \%$, ${ }^{* *} p<5 \%$ & & \\
\hline
\end{tabular}

Table 5 presents interesting results that all the squared terms of both temperature and rainfall under column (A) are statistically significant with varying levels of significance. While the squared terms of winter and summer temperature and rainfall have highly statically significant positive impacts spring and autumn temperature and rainfall have highly statistically significant negative impacts on net crop income implying non-linear relationship between climate variables and net crop income. The results also showed that all the interaction terms of temperature and rainfall column (B) are highly statistically significant except for the interaction term of autumn temperature and autumn rainfall, which also is not statistically significant. While the interaction terms of winter temperature and rainfall and summer temperature and rainfall have positive impact, spring temperature and rainfall has a highly statistically negative impact on net crop income. Mean annual temperature and rainfall have negative and positive impacts respectively indicating the 32 years climate change pressure on agriculture. Post estimation tests of model choice and time fixed effects were made. The Hausman test of model choice confirmed that (Prob $>$ chi2 $=0.0000$ ) fixed effect is the appropriate model and the time-fixed effect impact value of the Prob $>$ F $=0.02$ indicated time-fixed effect is indeed needed in the fixed effect model. 


\section{Discussion}

The main objective of the study was to examine the economic impacts of climate change on net crop income in the Nile basin Ethiopia using a Ricardian fixed effects panel data model. The study also aimed at examining the effects of methods of climate change adaptations on net crop income. Age of household head has a statistically significant negative effect on net crop income. This is because aged farmers do not intend to use adaptation strategies to climate change, application of improved crop varieties and other modern agricultural inputs in general to increase their agricultural production [63]. The size of a given household has a positive effect on agricultural productivity. In the work of [64], it was reported that larger household size increases agricultural productivity as larger family size means larger agricultural labor force available for work. The positive and significant impact of family size is also confirmed by [17]. Moreover, asset value (total estimated wealth) of farm households has also a positive significant impact on net crop income. This may be attributed to the fact that farmers with higher income status (wealth) have the tendency to improve their agricultural productivity through adapting to changing situations and shifting toward a sustainable approach [65]. When it comes to the impact of climate variables on net crop income, spring temperature, summer temperature, winter rainfall, spring rainfall, and summer rainfall have all a positive impact although with varying statistical significance levels. That means, whereas the positive impacts of spring temperature and spring rainfall are not statistically significant the positive coefficients of summer temperature, winter rainfall, and summer rainfall are all statistically significant. In contrast, autumn temperature and autumn rainfall have a significant negative impact on net crop income. The positive impact of spring temperature may be attributed to the opportunity for farmers to sow crops early that require long gestation periods such as maize and corn coupled with a positive impact of spring rainfall. The higher the spring rainfall, the sooner the plantation date that allows longer growing periods [46]. Increased summer temperature has a positive impact on relatively cooler regions. Autumn rainfall has a significant negative impact on the net crop income of farmers in the Nile basin region as autumn in this region is a harvesting season and unpredicted rainfall in this season happens to damage crops. In contrast to the findings of this study, ref. [34] found that increased winter and summer temperature have negative impact on Ethiopian agriculture. However, this study discovered the same results as [34] on the impacts of annual temperature and rainfall in which both studies agree that an increase in temperature reduces net crop incomes per hectare whereas increase in rainfall increases it. Seasonal temperature and rainfall have different estimated coefficients implying the variation in the impact of climate change across months and seasons [46]. The dummy coefficients of regions are different as the impact of climate change varies across regions coupled with variation in their adaptation capacities [6]. Although climate change is a global challenge, it is expected to have a blatant effect on the agricultural activities of developing countries like Ethiopia. The use of improved crop varieties is another technological intervention in the agriculture sector. As farmers are indeed efficient with what they have at their disposal, helping them to adapt to new technology was suggested to bring them out of poverty. Although Ethiopia is the origin of humankind and home of some indigenous crop species, there are huge problems and constraints for farmers to use and adapt the most promising crop varieties so that there would be high agricultural productivity in the country [66]. The analysis of the use of improved crop varieties showed a positive impact on net crop income as new agricultural technologies are promising ways to adapt to climate change [67]. Furthermore, ref. [68] pointed out that the adoption of improved maize variety leads to an increase in maize income. The logic behind the use of improved crop varieties is for a myriad of advantages, including drought resistance, yield, shelf life, early maturity, and many more advantages [68]. The issue of modeling irrigation in Ricardian models has been a deal among economists and agronomists [17]. Some economists' model irrigation as an exogenous variable to climate change impact on agriculture and some others argue that irrigation is endogenous to the system. However, many researchers have found that 
irrigation is one of the strategies to climate change adaptation and studies that on climate change impact should not omit it. For instance, ref. [47] found that irrigated farm lands are more sensitive to climate change than do rained lands. Moreover, ref. [17] also showed that the incorporation of irrigation in the system leads to lower estimates of climate variables which implies its leveraging effect of climate change on crop output. The economic analysis and stakeholder work enable the production of viable co-produced policy approaches incorporating feedback from local markets back to the national policy-making process [69]. Without this feedback, there is no climate adaptation and no incorporation of lessons learned during the process of implementation. The results of the research also well reflect the strong correlation between ecological efficiency and net income [70,71].

\section{Conclusions}

This study, relying on detailed farm household survey data in the Ethiopian Nile basin tried to add value to the existing endeavors by empirically estimating the economic impacts of climate change on the Ethiopian agriculture. The least squares dummy variable (LSDV) model showed that farmer characteristics including literacy, household size, remittance, asset value, and total land holdings have significant positive impacts on net crop income per hectare. On the other hand, age and average plot sizes are found to have negative impacts. Likewise, the fixed effects model of regressing net crop income on strategies to climate change adaptation resulted in significant and positive contributions in leveraging the damaging effects of climate change. Making a synthesis on the sign and significance level of seasonal mean temperature and rainfall-fixed effect estimates revealed the offsetting interactions among these seasonal climate change indicators. Winter temperature and rainfall are found to be significantly beneficial and positive irrespective of the models used and functional formulations. That means the linear, squared, and interaction terms of winter rainfall and temperature are important for increasing agricultural outputs in the study area. However, it was only the interaction term of spring temperature and rainfall significant and negative. Like that of winter temperature and rainfall, the different forms of summer rainfall and temperature have significant positive impacts on net crop income. This is because the damaging effect of high temperature can be settled by the high rainfall so that crops obtain the optimum combination of both summer temperature and rainfall. Autumn temperature and rainfall estimates revealed that both increased temperature and rainfall reduce net crop income. The sign and significance of the estimates of climate variables were consistent indicating the robustness of the results and the model. Ecological capacities are constantly changing under the impact of climate change, increasing and decreasing simultaneously, and the same trend is followed by individual crop yields and associated incomes. The methodological contribution of this study is its confirmation of the highly statistically important impacts of the interaction terms of seasonal temperature and rainfall variables on net crop income.

Author Contributions: Conceptualization, M.M.B. and C.F.; methodology, M.M.B.; formal analysis, M.M.B. and C.F.; investigation, M.M.B.; resources, M.M.B. and C.F.; data curation, M.M.B.; writingoriginal draft preparation, M.M.B.; writing-review and editing, C.F.; supervision, C.F.; project administration, M.M.B. and C.F.; funding acquisition, C.F. All authors have read and agreed to the published version of the manuscript.

Funding: Special thanks to the Hungarian National Research, Development and Innovation OfficeNKFIH (Program ID: OTKA 131925).

Institutional Review Board Statement: Not applicable.

Informed Consent Statement: Informed consent was obtained from all subjects involved in the study.

Data Availability Statement: Not applicable.

Conflicts of Interest: The authors declare no conflict of interest. 


\section{References}

1. Closset, M.; Dhehibi, B.B.B.; Aw-Hassan, A. Measuring the economic impact of climate change on agriculture: A Ricardian analysis of farmlands in Tajikistan. Clim. Dev. 2015, 7, 454-468. [CrossRef]

2. Barbante, C. Climate Change Impacts and Efficient Adaptation Options in the Bolivian Agriculture. Ph.D. Thesis, Università Ca' Foscari, Venice, Italy, 2014.

3. Lone, B.A.; Qayoom, S.; Singh, P.; Dar, Z.A.; Kumar, S.; Dar, N.; Fayaz, A.; Ahmad, N.; Bhat, L.M.I.; Singh, G. Climate Change and Its Impact on Crop Productivity. Br. J. Appl. Sci. Technol. 2017, 21, 1-15. [CrossRef]

4. Auffhammer, M. Quantifying economic damages from climate change. J. Econ. Perspect. 2018, 32, 33-52. [CrossRef]

5. IPCC. Proposed Outline of the Special Report in 2018 on the Impacts of Global Warming of $1.5^{\circ} \mathrm{C}$ above Pre-Industrial Levels and Related Global Greenhouse Gas Emission Pathways, in the Context of Strengthening the Global Response to the Threat of Climate Change. 2018. Available online: http:/ / www.environmentalgraphiti.org. (accessed on 25 May 2021).

6. Lin, T.; Liu, X.; Wan, G.; Xin, X.; Zhang, Y. ADB Economics Working Paper Series Climate Change and Agricultural in the Peoples Republic of China. 2011. Available online: https://www.adb.org/sites/default/ files/publication/28433/economics-wp243.pdf (accessed on 25 May 2021).

7. Mutua, P.; Goda, K. Multidimensional assessment of European agricultural sector adaptation to climate change. Stud. Agric. Econ. 2021, 123, 8-22. [CrossRef]

8. Organisation for Economic Co-operation and Development (OECD). Agriculture and Climate Change: Towards Sustainable, Productive and Climate-Friendly Agricultural Systems. 2016. Available online: http:/ /www.oecd.org/tad/sustainable-agriculture/ 4_background_note.pdf (accessed on 25 May 2021).

9. Smith, D.L.; Almaraz, J.J. Climate change and crop production: Contributions, impacts, and adaptations. Can. J. Plant Pathol. 2004, 26, 253-266. [CrossRef]

10. Hamere, Y. A Review on Relationship between Climate Change and Agriculture. J. Earth Sci. Clim. Chang. 2016, 7, 335. [CrossRef]

11. Issoufou, A.A.; Soumana, I.; Maman, G.; Konate, S.; Mahamane, A. Dynamic relationship of traditional soil restoration practices and climate change adaptation in semi-arid Niger. Heliyon 2020, 6, 1-7. [CrossRef]

12. Mandryk, M. Integrated Assessment of Farm Level Adaptation to Climate Change in Agriculture-An Application to Flevoland, The Netherlands. Ph.D. Thesis, Wageningen University \& Research, Wageningen, The Netherlands, 2016.

13. Roco, L.; Engler, A.; Bravo-Ureta, B.; Jara-Rojas, R. Farm level adaptation decisions to face climatic change and variability: Evidence from Central Chile. Environ. Sci. Policy 2014, 44, 86-96. [CrossRef]

14. Palatnik, R.R.; Roson, R. Climate change and agriculture in computable general equilibrium models: Alternative modeling strategies and data needs. Clim. Chang. 2012, 112, 1085-1100. [CrossRef]

15. Khan, I.; Lei, H.; Shah, I.A.; Ali, I.; Khan, I.; Muhammad, I.; Huo, X.; Javed, T. Farm households risk perception, attitude and adaptation strategies in dealing with climate change: Promise and perils from rural Pakistan. Land Use Policy 2020, $91,104395$. [CrossRef]

16. Anderson, R.; Bayer, P.E.; Edwards, D. Climate change and the need for agricultural adaptation. Curr. Opin. Plant Biol. 2020, 56, 197-202. [CrossRef]

17. Trinh, N.C.; Frank, S. Heterogeneous Impacts of Climate Change-The Ricardian Approach Using Vietnam Micro-Level Panel Data. In Proceedings of the New Zealand Agricultural \& Resource Economics Society (NZARES) Conference, Hamilton, New Zealand, 29-30 August 2018.

18. File, D.J.; Derbile, E.K. Sunshine, temperature and wind: Community risk assessment of climate change, indigenous knowledge and climate change adaptation planning in Ghana. Int. J. Clim. Chang. Strateg. Manag. 2020, 12, 22-38. [CrossRef]

19. World Bank. Economics of Adaptation to Climate Change: Ethiopia; World Bank: Washington, DC, USA, 2010.

20. Ingwersen, W.W.; Garmestani, A.S.; Gonzalez, M.A.; Templeton, J.J. A systems perspective on responses to climate change, Clean Technol. Environ. Policy 2014, 16, 719-730. [CrossRef]

21. Cradock-Henry, N.A.; Blackett, P.; Hall, M.; Johnstone, P.; Teixeira, E.; Wreford, A. Climate adaptation pathways for agriculture: Insights from a participatory process. Environ. Sci. Policy 2020, 107, 66-79. [CrossRef]

22. Ojo, T.; Baiyegunhi, L. Determinants of climate change adaptation strategies and its impact on the net farm income of rice farmers in south-west Nigeria. Land Use Policy 2020, 95, 103946. [CrossRef]

23. Verburg, R.; Rahn, E.; Verweij, P.; van Kuijk, M.; Ghazoul, J. An innovation perspective to climate change adaptation in coffee systems. Environ. Sci. Policy 2019, 97, 16-24. [CrossRef]

24. Scoville-Simonds, M.; Jamali, H.; Hufty, M. The Hazards of Mainstreaming: Climate change adaptation politics in three dimensions. World Dev. 2020, 125, 104683. [CrossRef]

25. Ensor, J.E.; Wennström, P.; Bhatterai, A.; Nightingale, A.J.; Eriksen, S.; Sillmann, J. Asking the right questions in adaptation research and practice: Seeing beyond climate impacts in rural Nepal. Environ. Sci. Policy 2019, 94, 227-236. [CrossRef]

26. Afriyie-Kraft, L.; Zabel, A.; Damnyag, L. Adaptation strategies of Ghanaian cocoa farmers under a changing climate. For. Policy Econ. 2020, 113, 102115. [CrossRef]

27. Zhang, L.; Ruiz-Menjivar, J.; Luo, B.; Liang, Z.; Swisher, M.E. Predicting climate change mitigation and adaptation behaviors in agricultural production: A comparison of the theory of planned behavior and the Value-Belief-Norm Theory. J. Environ. Psychol. 2020, 68, 101408. [CrossRef] 
28. Xin, Y.; Tao, F. Developing climate-smart agricultural systems in the North China Plain. Agric. Ecosyst. Environ. 2020, $291,106791$. [CrossRef]

29. Welteji, D. A critical review of rural development policy of Ethiopia: Access, utilization and coverage. Agric. Food Secur. 2018, 7 , 1-6. [CrossRef]

30. Berhanu, K.; Poulton, C. The Political Economy of Agricultural Extension Policy in Ethiopia: Economic Growth and Political Control. Dev. Policy Rev. 2014, 32, s197-s213. [CrossRef]

31. Gebre-Selassie, S. The Role of Agriculture in the Development Process: Recent Experiences and Lessons from Ethiopia, Inaug Symp. In Proceedings of the African Association of Agricultural Economists (AAAE), Nairobi, Kenya, 6-8 December 2004.

32. Alemu, Z.G.; Oosthuizen, K.; Van Schalkwyk, H.D. Contribution of agriculture in the Ethiopian economy: A time-varying parameter approach. Agrekon 2003, 42, 29-48. [CrossRef]

33. FAO. The Future of Livestock in Ethiopia: Opportunities and Challenges in the Face of Uncertainty; FAO: Rome, Italy, 2019.

34. Deressa, T.T. Measuring the Economic Impact of Climate Change on Ethiopian Agriculture: Ricardian Approach. Soc. Sci. Res. Netw. 2007, 4342, 32.

35. Legesse, S.A. Ethiopian summer temperature from the global circulation model output data and its outlooks. Environ. Syst. Res. 2016, 5, 1-12. [CrossRef]

36. Di Falco, S.; Yesuf, M.; Köhlin, G.; Ringler, C. Estimating the Impact of Climate Change on Agriculture in Low-Income Countries: Household Level Evidence from the Nile Basin, Ethiopia. Environ. Resour. Econ. 2012, 52, 457-478. [CrossRef]

37. Zhai, F.; Lin, T.; Byambadorj, E. A general equilibrium analysis of the impact of climate change on agriculture in the people's Republic of China. Asian Dev. Rev. 2009, 26, 206-225.

38. Mendelsohn, R.; Dinar, A. Climate change and agriculture: An economic analysis of global impacts, adaptation and distributional effects. EuroChoices 2010, 9, 51. [CrossRef]

39. Carter, C.; Cui, X.; Ghanem, D.; Mérel, P. Identifying the Economic Impacts of Climate Change on Agriculture. Annu. Rev. Resour. Econ. 2018, 10, 361-380. [CrossRef]

40. Mendelsohn, R.; Nordhaus, W.D.; Shaw, D. The impact of global warming on agriculture: A ricardian analysis. Clim. Chang. 1994, $84,753-771$.

41. Deschenes, O.; Greenstone, M. MIT Joint Program on the Science and Policy of Global Change the Economic Impacts of Climate Change: Evidence from Agricultural Profits and Random Fluctuations of Weather. Am. Econ. Rev. 2006, 131, 1-51.

42. Severen, C.; Costello, C.; Deschênes, O. A Forward-Looking Ricardian Approach: Do land markets capitalize climate change forecasts? J. Environ. Econ. Manag. 2018, 89, 235-254. [CrossRef]

43. Mendelsohn, R.O.; Massetti, E. The use of cross-sectional analysis to measure climate impacts on agriculture: Theory and evidence. Rev. Environ. Econ. Policy 2017, 11, 280-298. [CrossRef]

44. Mendelsohn, R.; Dinar, A. The effect of development on the climate. Environ. Dev. Econ. 2001, 6, 85-101. [CrossRef]

45. Gebreegziabher, Z.; Stage, J.; Mekonnen, A.; Alemu, A. Climate Change and the Ethiopian Economy: A Computable General Equilibrium Analysis; Resources for the Future: Washington, DC, USA, 2011.

46. Massetti, E.; Mendelsohn, R. Estimating Ricardian Models with Panel Data. Clim. Chang. Econ. 2011, 2, 301-319. [CrossRef]

47. Luis, M.G.; Orlando, R. Climate change, irrigation and agricultural activities in Mexico: A Ricardian analysis with panel data. J. Dev. Agric. Econ. 2015, 7, 261-272. [CrossRef]

48. Vaitkeviciute, J. The climate effects on European agriculture: A Ricardian Approach, 2010. 2012. Available online: http: / / faere.fr/pub/Conf2017/FAERE2017_Vaitkeviciute.pdf (accessed on 25 May 2021).

49. Gaál, M.; Quiroga, S.; Fernandez-Haddad, Z. Potential impacts of climate change on agricultural land use suitability of the Hungarian counties. Reg. Environ. Chang. 2014, 14, 597-610. [CrossRef]

50. Fezzi, C.; Bateman, I.J. The Impact of Climate Change on Agriculture: Nonlinear Effects and Aggregation Bias in Ricardian Models of Farm Land Values. SSRN Electron. J. 2013. [CrossRef]

51. Fezzi, C.; Bateman, I. The impact of climate change on agriculture: Nonlinear effects and aggregation bias in ricardian models of farmland values. J. Assoc. Environ. Resour. Econ. 2015, 2, 57-92. [CrossRef]

52. CSA. Projected Population of Ethiopia for 2011/2019, Addis Ababa, 2019. [Online]. Available online: https://www.statsethiopia. gov.et/wp-content/uploads/2019/11/Projected-Population-of-Ethiopia-20112019.pdf (accessed on 25 May 2021).

53. Yalew, A.W.; Hirte, G.; Lotze-Campen, H.; Tscharaktschiew, S. Economic Effects of Climate Change in Developing Countries: EconomyWide and Regional Analysis for Ethiopia; CEPIE Working Papers: Washington, DC, USA, 2017.

54. Ringler, C.; Sun, Y. Ethiopia Nile Basin Climate Change Adaptation Dataset, International Food Policy Research Institute. 2010. Available online: https:/ / dataverse.harvard.edu/api/datasets / export?exporter=html\&persistentId=doi\%3A10.7910/DVN/ LG8QLB (accessed on 24 May 2021).

55. Mendelsohn, R.; Nordhaus, W.D.; Shaw, D. The Impact of Climate on Agriculture: A Ricardian Approach. In Costs, Impacts, and Benefits of $\mathrm{CO}_{2}$ Mitigation; Kaya, Y., Nakicenovic, N., Nordhaus, W., Toth, F., Eds.; International Institute of Applied Systems Analysis: Laxenburg, Austria, 1993; pp. 173-175.

56. Jawid, A. A Ricardian analysis of the economic impact of climate change on agriculture: Evidence from the farms in the central highlands of Afghanistan. J. Asian Econ. 2020, 67, 101177. [CrossRef]

57. Gujarati, D. Basic Econometrics; Palgrave Macmillan: London, UK, 2011.

58. Veblen, T. History of Economic Thought Books; Batoche Books: Kitchener, ON, Canada, 2001; p. 379. 
59. Chatzopoulos, T. Microeconometric Analysis of the Impacts of Climate Change on German Agriculture: Applications and Extensions of the Ricardian Approach; ResearchGate: Berlin, Germany, 2015.

60. Torres-Reyna, O. Panel Data Analysis Fixed and Random Effects Using Stata (v. 4.2). 2007. [Online]. Available online: http:/ / dss.princeton.edu/training/ (accessed on 25 May 2021).

61. Hsiao, C. Analysis of Panel Data, 3rd ed.; Cambridge University Press: Cambridge, UK; New York, NY, USA; Madrid, Spain; Cape, South Africa, 2014.

62. Hsiao, C. Analysis of Panel Data, 2nd ed.; Cambridge University Press: Cambridge, UK; New York, NY, USA; Madrid, Spain; Cape, South Africa, 2008.

63. Makuvaro, V.; Walker, S.; Masere, T.P.; Dimes, J. Smallholder farmer perceived effects of climate change on agricultural productivity and adaptation strategies. J. Arid Environ. 2018, 152, 75-82. [CrossRef]

64. Ojiya, E.; Ameh, O.E.; Sunday, O.A.; Baajon, M.A.; Chukwuemeka, N.J. An Empirical Analysis of the effect of Agricultural Input on Agricultural Productivity in Nigeria. Int. J. Agric. Sci. Food Technol. 2017, 3, 77-85. [CrossRef]

65. Grzelak, A.; Staniszewski, J.; Borychowski, M. Income or assets-What determines the approach to the environment among farmers in a region in Poland? Sustainability 2020, 12, 4917. [CrossRef]

66. Asrat, S.; Yesuf, M.; Carlsson, F.; Wale, E. Farmers preferences for crop variety traits: Lessons for on-farm conservation and technology adoption. Ecol. Econ. 2010, 69, 2394-2401. [CrossRef]

67. Asfaw, S.; Shiferaw, B.; Simtowe, F.; Lipper, L. Impact of modern agricultural technologies on smallholder welfare: Evidence from Tanzania and Ethiopia. Food Policy 2012, 37, 283-295. [CrossRef]

68. Khonje, M.; Manda, J.; Alene, A.D.; Kassie, M. Analysis of Adoption and Impacts of Improved Maize Varieties in Eastern Zambia. World Dev. 2015, 66, 695-706. [CrossRef]

69. Hutton, C.; Hensengerth, O.; Berchoux, T.; Tri, V.; Tong, T.; Hung, N.; Voepel, H.; Darby, S.; Bui, D.; Bui, T.; et al. Stakeholder Expectations of Future Policy Implementation Compared to Formal Policy Trajectories: Scenarios for Agricultural Food Systems in the Mekong Delta. Sustainability 2021, 13, 5534. [CrossRef]

70. Tóth, G.; Szigeti, C.; Harangozó, G.; Szabó, D.R. Ecological Footprint at the Micro-Scale—How It Can Save Costs: The Case of ENPRO. Resources 2018, 7, 45. [CrossRef]

71. Wei, T.; Zhang, T.; Cui, X.; Glomsrød, S.; Liu, Y. Potential influence of climate change on grain self-sufficiency at the country level considering adaptation measures. Earths Future 2019, 7, 1152-1166. [CrossRef] 